\title{
RECENT WORK ON THYROID HORMONES
}

\author{
By J. H. Wilkinson, B.Sc., Ph.D., F.R.I.C. \\ Reader in Chemical Pathology, University of London (Westminster Medical School)
}

Progress in research frequently awaits the application of new techniques developed in unrelated fields. The biochemistry of the thyroid gland is a particularly good example, for remarkable advances have followed the introduction of paper chromatography and autoradiography with radioactive iodine $\left({ }^{131} \mathrm{I}\right)$.

Classical methods had previously shown that the circulating form of thyroid hormone was the free amino-acid thyroxine, and that this compound was produced in the gland by a series of processes substantially as suggested by Harington and Barger (1927). A number of investigators, however, found that the metabolic activities of thyroid extracts could not be correlated with their thyroxine contents, an anomaly for which recent work has provided a probable explanation.

\section{Discovery of Triiodothyronine}

Paper chromatographic studies of butanol extracts of thyroid tissue and plasma of rats previously treated with ${ }^{131} \mathrm{I}$, showed the presence of hitherto unsuspected iodine-containing compounds, the principal one of which was provisionally designated 'Compound No. r.' This substance was subsequently found in the tissues of intact and thyroidectomized mice after the injection of ${ }^{131} \mathrm{I}$-labelled thyroxine (Gross and Leblond, 195 I), and also in the plasma of patients treated with therapeutic doses of ${ }^{131}$ I (Gross and Pitt-Rivers, 195I).

Rapid progress followed when Gross and PittRivers (1952a) identified this unknown compound as 3:5:3'-triiodothyronine (Fig. I), the isolation and synthesis of which were simultaneously reported by Roche, Lissitzky and Michel (1952a, b). The importance of this discovery became evident when the high physiological activity of triiodothyronine was established. When tested by a variety of methods, triiodothyronine proved to be about five times as active as thyroxine, an observation which prompted Gross and Pitt-Rivers (r952b) to suggest that the new compound might be the active form of thyroid hormone and thyroxine its precursor. This theory will be discussed later.

Clinical trials confirmed the high activity of triiodothyronine and it was successfully used in the treatment of myxoedema (Gross, Pitt-Rivers and Trotter, 1952). Rawson and his co-workers (1953) and Lerman (1953), however, failed to obtain the clinical response expected as a result of the animal investigations. They obtained a more rapid increase in the basal metabolic rate of a myxoedematous patient with triiodothyronine than with thyroxine, but subsequent treatment with thyroxine produced a more prolonged effect. Their results were attributed to the more rapid disappearance of triiodothyronine from the circulation. A similar conclusion was reached by Maclagan and Wilkinson (1954) as a result of excretion studies in rats.

Radioactive iodine ( $\left.{ }^{131} \mathrm{I}\right)$ was used in the work discussed above and the possibility remained that triiodothyronine might be an artifact released as a result of radiation damage to the gland. However, a technique for the chromatography of circulating thyroid hormones, which has recently been devel-ro oped, has enabled the presence of triiodothyronine? to be confirmed in the plasma of normal and thyrotoxic individuals without using radioactive materials (Maclagan, Bowden and Wilkinson, 1955).

\section{Origin of Triiodothyronine}

The suggestion that triiodothyronine might be the peripherally active form of thyroid hormone, received support from the observations of Maclagan, Sprott and Wilkinson (1952) who found that the anti-thyroxine compound, butyl 4-hydroxy-3:5-diiodobenzoate (BHDB) (Fig. r), enhanced the action of triiodothyronine in raising the oxygen consumption of mice. This observation was explained on the assumption that BHDB interfered with deiodination processes, thus inhibiting the action of thyroxine by preventing its conversion into the active form, triiodothyronine. If further deiodination of the latter into inactive compounds were also inhibited by BHDB, the augmentation of its metabolic effects would follow. The observation by Barker, Dirks, Garlick and Klitgaard (195r) that BHDB also antagonized thyroxine in thyroidectomized rats was in agreement with this hypothesis.

It has long been known that the administration of large doses of thyroxine produces an increased 
но

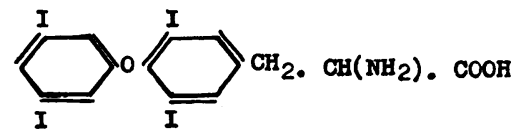

Thyroxine<smiles>O=C(O)CCCCCCCCCCCCCCCCCOc1ccccc1</smiles>

3:5:3'-Trilodothyronine
HO<smiles>CCCCC(=O)OCc1ccccc1</smiles>

Butyl 4-Hydroxy-3:5-dilodobenzoto output of urinary iodide, and the use of ${ }^{131} \mathrm{I}$ labelled thyroxine has enabled these results to be confirmed by more specific methods using physiological doses of the hormone. Definite evidence in support of the deiodination suggestion was obtained, when it was shown that the output of urinary iodide, following the injection of ${ }^{131} \mathrm{I}$ labelled thyroxine or triiodothyronine into normal rats, was reduced by simultaneous administration of BHDB (Wilkinson, Sprott, Bowden and Maclagan, 1954). Similar results were obtained in thyroidectomized rats by Wilkinson and Feetham (1955), though it had earlier been reported that BHDB appeared to cause increased deiodination of radiothyroxine in such animals.

Further evidence for the conversion of thyroxine into triiodothyronine was obtained by Kalant, Lee and Sellers (r955) who injected 131I-labelled thyroxine into normal and propylthiouraciltreated rats. Extracts of various tissues were chromatographed and radioactive triiodothyronine was shown to be present. Pitt-Rivers, Stanbury and Rapp (1955) demonstrated the same process in each of six hypothyroid patients treated with labelled thyroxine. Paper chromatograms of plasma extracts were shown to contain radioactive triiodothyronine. Such deiodination processes have been shown to occur in rat liver homogenates (Maclagan and Sprott, 1954), while Albright, Larson and Tust (1955) detected the presence of triiodothyronine in rat kidney slice preparations treated with thyroxine, an observation which has since been confirmed and extended.

Though the evidence for the peripheral conversion of thyroxine into triiodothyronine is very strong, the possibility remains that the triiodo compound is synthesized in the thyroid gland and secreted directly into the circulation along with thyroxine. The demonstration that monoiodo- tyrosine as well as diiodotyrosine is present in the gland, led several workers to consider the possibility that triiodothyronine could be produced the condensation of one molecule of the former with one of the latter (Roche and Michel, 1954). Such a process would be analogous with the route suggested by Harington and Barger (1927) for t5e biosynthesis of thyroxine and substantially confirmed by much later work. It seems highly posouable that thyroidal triiodothyronine mighe be formed in this way, for it has been shown that the gland the proportion of triiodothyrowise relative to thyroxine is increased when animals ate fed on diets deficient in iodine. On the oth hand, no such change was observed in the serum relations of the two compounds.

Benua, Dobyns and Ninmer (1955) treated $\frac{\overrightarrow{0}}{\$^{2}}$ patients with radio-iodide and in 27 cases they detected the presence of triiodothyronine in the plasma, sometimes as early as one hour after the administration of the radio-iodide. These authợ have interpreted this early appearance as indicatiog that triiodothyronine did not arise as the result of radiation damage nor of peripheral deiodination, but that it came from the gland. Such a conclusion is supported by Taurog, Wheat and Chaik off (1956) who observed that triiodothyronine was more readily detectable in the thyroid veins than in the peripheral circulation of farm animats previously treated with radio-iodide. The tifiodothyronine amounted to about ro to $20 \mathrm{pger}$ cent. of the thyroxine content in the thyroid vent, a ratio similar to that found in the gland itself.

The results discussed above imply that thiiodothyronine arises both by synthesis in the glaFi $d$ and by peripheral deiodination of thyroxime. Owing to its more rapid rate of diffusion it is probable that triiodothyronine will tend to dis 2 pear from the circulation more rapidly than th 


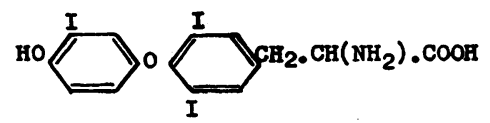

Trilodothyronine

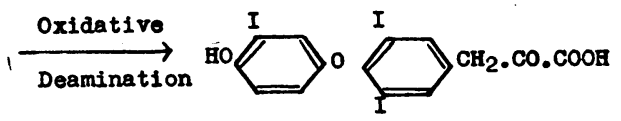

Trilodothyropyruvic Acld

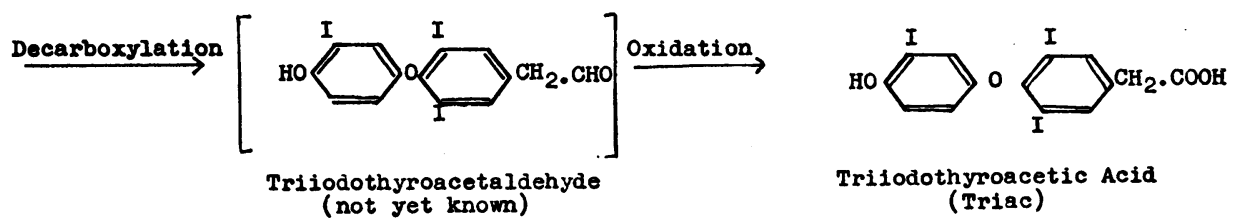
FIO. 2. - Probable route for the enzymic conversion of trilodothyronine into
trilodothyroacetic acid (triac). Thyroxine appears to undergo similar
conversion into tetrac.

roxine, and it seems that the circulating level might be maintained by a fine adjustment mechanism involving the deiodination of thyroxine.

Whatever the main route of triiodothyronine biosynthesis might be, there is a strong suggestion that failure in the deiodination process may be of clinical importance. Kurland, Hamolsky and Freedberg (1955) have described four patients with low metabolic rates who showed no improvement when treated with thyroxine, but who responded satisfactorily to triiodothyronine. Among other suggestions these authors indicated that peripheral conversion might be impaired in these patients. Maclagan and Reid (1956) have recently extended earlier work on rat liver homogenates, and have extracted an enzyme system which catalyses the deiodination of thyroxine and triiodothyronine. This system is inhibited by anaerobic conditions, heat, cyanide, BHDB and, to a lesser extent, by iodide. It is conceivable that such an enzyme was either absent or inhibited in the patients described by Kurland $e t$ al.

\section{Acetic Acid Analogues of Thyroxine}

Several hundred chemical analogues of thyroxine have been prepared and examined for biological activity. Some of these, like BHDB, exerted a thy oxine-inhibitory effect whilst certain others displayed thyroxine-like activity. Of the latter, the acetic acid analogues of thyroxine (tetrac) (Harington and Pitt-Rivers, 1952) and of triiodothyronine (triac) (Pitt-Rivers, 1953) have exhibited some very interesting effects. Both compounds were shown to increase the metabolic rate in rats and to have about one-tenth of the activity of triiodothyronine in the goitre prevention test.

The latent period between the administration of thyroxine and triiodothyronine and the onset of their biological effects has presented a problem, but when Thibault and Pitt-Rivers (1955) demonstrated that both triac and tetrac produced an immediate rise in the oxygen consumption of ratkidney slices and in the basal metabolic rate of thyroidectomized rats, it seemed that a possible explanation was forthcoming. These results suggested that during the latent period the iodothyronines were being converted into the acetic acid derivatives. This result could arise by a process of oxidative deamination of the alanine side? chains to the corresponding pyruvic acids, which could then undergo decarboxylation and oxidation to the acetic acids (Fig. 2). All these processes are known to occur in biological systems.

Immediate effects were also observed by Heimberg, Park, Isaacs and Pitt-Rivers (1955) who found that triac and tetrac stimulated aerobic glycolysis in ascites tumour cells in vitro. No such effect could be detected with triiodothyronine. On the other hand, Dickens and Salmony (1956) have reported their inability to confirm the enhanced rate of respiration of rat-kidney slices found by Thibault and Pitt-Rivers. Meanwhile, two groups of workers have demonstrated chromatographically the conversion of the iodothyronines into triac and tetrac in rat kidney preparations (Roche, Michel, Jouan and Wolf, 1955; Albright, Larson, Tomita and Lardy, 1956).

Clinical trials showed that triac was of value in the treatment of myxoedema. Lerman and PittRivers (1955, 1956) found that, in doses of less than $1.5 \mathrm{mg}$. daily, triac produced little change in the basal metabolic rate, but caused a substantial fall in the plasma cholesterol, and an increase in urinary creatine, as well as considerable improvement in clinical condition. In larger doses it behaved like thyroxine, except that the increase in 
the basal metabolic rate was produced in a few hours and had subsided completely within 24 hours. Trotter (1955) confirmed that triac was useful in the treatment of myxoedema, but was unable to detect any immediate effect on the basal metabolic rate.

The suggestion that triac had a greater effect on the plasma cholesterol than on the basal metabolic rate has attracted considerable attention, and Trotter (1956a) reported that it had a relatively greater action on the cholesterol level than thyroxine, but that triiodothyronine had 75 times its activity on both cholesterol content and basal metabolic rate. In euthyroid subjects treated with 3-4 mg. triac daily, no rise in the basal metabolic rate was observed and the cholesterol level was reduced. Similar results were obtained when four euthyroid patients with coronary artery disease were treated with triac (Trotter, 1956b). Tetrac also appeared to affect the plasma cholesterol more than the basal metabolic rate, in the case of myxoedema studied by Goolden (1956). On the other hand, several investigators consider that the plasma cholesterol is more sensitive to the smallest doses of any thyroid hormone than the basal metabolic rate, and it has yet to be shown whether the actions of triac and tetrac differ qualitatively from those of triiodothyronine and thyroxine.

\section{Other Analogues of Thyroxine}

Two further analogues of thyroxine, $3: 3^{\prime}$-diiodothyronine and $3^{\prime}: 5^{\prime}: 3^{-}$-triiodothyronine, have been detected in enzymic hydrolysates of gland extracts. The former, which was also found in the plasma of rats treated with radioiodide (Roche, Michel, Nunez and Wolf; 1955), has about 75 per cent. of the antigoitrogenic activity of thyroxine. Although the French workers have detected this compound in rat plasma on many occasions, no evidence for its presence in human plasma was found in the writer's laboratory, during a study in which the circulating thyroid hormones of about 50 subjects in various states of thyroid activity were examined by non-radioactive techniques.

\section{Metabolism of Thyroid Hormones}

After the administration of a single dose of radioactive thyroxine or triiodothyronine to rats, about 20 per cent. of the former and about 25 per cent. of the latter appeared as urinary iodide (Maclagan and Wilkinson, 1954). This arose as a result of deiodination processes discussed above. The faecal radioactivity accounted for the greater part of either hormone, but in the case of thyroxine the output varied from 40 per cent. of small physiological doses (4 $\mathrm{\mu g}$./rat) to about 75 per cent. with large doses (100 $\mu$ g./rat). About 50 per cent. of the triiodothyronine was recovered in the faeces irrespective of the dose. These results indicat that the liver appears to deal more effectively with large amounts of thyroxine than with simil quantities of triiodothyronine.

The nature of the substances excreted in the bile has been studied in rats by Roche, Michel and Tata (1954) who found that, in addition to being excreted partly as glycuronides, both thyroxine and triiodothyronine gave rise to the corresponding pyruvic acid compounds to which reference has already been made. The pyruvic acid deriveg from thyroxine was reabsorbed into the portan circulation and some appeared in the urine. Thio glycuronides were not normally found in the plasma except after ligation of the bile duct.

It is to be expected that in certain liver diseases these excretory processes might be impaired, anf the level of circulating thyroid hormones might bes raised. Vannotti (1956) has recently reported the interesting observation that in both infective hepas titis and obstructive jaundice in man, the plasma protein bound iodine was increased. In hepatitis the increase was due to an accumulation of free thyroxine presumably because glycuronide synthesis was interrupted, whereas in obstructive jaundice glycuronides appeared in the plasma. thyrotoxic symptoms are not normally encountered in hepatitis, it would seem that Vannotti's obsefra tions provide additional evidence for the view thyroxine per se has little or no biological acti

\section{Mode of Action of Thyroid Hormones \\ Our knowledge of the intracellular actions of} thyroid hormones remains scanty, though sever 1 groups of workers have studied the subject singe 2:4-dinitrophenol (DNP) was reported to preve the energy, liberated during the oxidation of glut amic acid in mitochondrial preparations, frow being used in the synthesis of energy-rich phos phate bonds. Thyroxine and a number of other. halophenols were subsequently shown to produce a similar uncoupling of oxidative phosphorylation (Lardy and Feldott, I95I; Martius and Hes8, 195I). Hoch and Lipmann (1954) found that triiodothyronine was somewhat less effective thas thyroxine, but they considered that because of its easier permeation, the greater over-all activity the former in the whole animal could be reconcile with its lesser effect on the mitochondria.

These observations were made with mitochon rial preparations from rats previously treated with thyroxine, or with mitochondria pre-incubated with the hormone. That a latent period wass necessary before the hormone became effective wo్ss confirmed by Klemperer (1955). By contrat Dickens and Salmony (1956) found that triac and tetrac produced an immediate effect.

It would seem that within the cell thyreid ho 
mones can interfere with the storage of energy resulting from oxidative processes. Such a concept would provide an excellent explanation for the wasteful dissipation of energy in hyperthyroid states, but not for the normal physiological action of thyroid hormones. A further difficulty is that the anti-thyroxine compound, BHDB, is one of the most effective uncoupling agents (Hoch and Lipmann, 1954). The theory remains, however, a most important line of inquiry and may well lead to results of fundamental value.

\section{Conclusion}

In such a rapidly expanding field, the writer finds it difficult to draw definite conclusions which are not liable to be exploded by new discoveries, but certain general comments may be permitted.

It seems fairly certain from its latent period, studies of antithyroxine compounds, its high plasma level in hepatitis and its inactivity in certain hypometabolic patients, that thyroxine requires conversion into some other form before it becomes active. The nature of the active form is a matter for speculation, but it is probable that triiodothyronine is a step in the process because of its high overall activity. This substance is unlikely to be the end-product for it too has a latent period which, however, seems to be shorter than that of thyroxine. The compounds triac and tetrac, which appear to produce immediate effects at least in some tests, may well be the active forms of the hormone.

On the other hand Barker (1956) has suggested that the physiological activity of the thyroid hormones may be the resultant of a whole spectrum of compounds, and it may be quite futile to attempt to characterize any one substance as the active form.

\section{BIBLIOGRAPHY}

ALBRIGHT, E. C., LARSON, F. C., and TUST, R. H. (1954), Proc. Soc. exp. Biol. (N.Y.), 86, 137 .

ALBRIGHT, E. C., LARSÖN, F. C., TOMITA, K., and

LARDY, H. A. (1956), Endocrinology, 59, 252.

BARKER, S. B. (1956), Private communication.
BARKER, S. B., DIRKS, H. B., Jr., GARLICK, W. R., and KLITGAARD, H. M. (I95I), Proc. Soc. exp. Biol. (N.Y.), 78,840 .

BENUA, R. S., DOBYNS, B. M., and NINMER, A. (1955), F. clin. Endocr., $15,1367$.

DICKENS, F., and SALMONY, D. (1956), Biochem. F., 64, 645. GOOLDEN, A. W. G. (1956), Lancet, i, 890 .

GROSS, J., and LEBLOND, C. P. (I951), Proc. Soc. exp. Biol. $(N . Y), 76,$.

GROSS, J., and PITT-RIVERS, R. (195I) Lancet, ii, 766.

GROSS, J., and PITT-RIVERS, R. (1952a), Ibid., i, 439.

GROSS, J., and PITT-RIVERS, R. (I952b) Ibid., 439.

GROSS, J., PITT-RIVERS, R., and TROTTER,'W. R.' (I952), Ibid., i, 1044

HARINGTON, C. R., and BARGER, G. (1927), Biochem. $\mathfrak{F}$., 2I, I69.

HARINGTON, C. R., and PITT-RIVERS, R. (I952), Ibid.,

HEIMBERG, M., PARK, J. H., ISAACS, A., and PITT-RIVERS,

R. (1955), Endocrinology, $57,756$.
HOCH. F. L., and LIPMANN, F. (1954), Proc. nat. Acad. Sci. (Wash.), 40, 909.

KALANT, H., LEE, R., and SELLERS, E. A. (1955), Endocrinology, 56, 127.

KLEMPEKER, H. G. (1955), Biochem. F. 60, 122.

KURLAND, G. S., HAMOLSKY, M. W., and FREEDBERG,

A. S. (1955), $\mathcal{F}$. clin. Endocr., 15, 1354.
LARDY, H. A., and FELDOTT, G. (1951), Ann. N.Y. Acad. Sci., 54,636 .

LERMAN, J. (1953), f. clin. Endocr., 13, 134 I.

LERMAN, J., and PITT-RIVERS,' R. (1955), Ibid., 15, 653.

LERMAN, J., and PITT-RIVERS, R. (I956), Ibid., I6, I470.

MACLAGAN, N. F., BOWDEN, C. H., and WILKINSON, J. H. (1955), Rec. Trav. chim. Pays-Bas, 74, 633 .

MACLAGAN, N. F., and REID, D. N. (1956), 'Ciba Found.

Colloq. Endocrinol.' In the press. MACLAGAN, N. F., SPROTT, W. E., and WILKINSOKN, J. H. (1952), Ibi.d., ii, 15 .

MACLAGAN, N. F., and WILkINSON, J. H. (1954), f. Physiol. (Lond.), 123, 405 .

MARTIUS, C., and HESS, B. (1951), Arch. Biochem. Biophy s. 33, 486.

PITT-RIVERS, R. (1953), Lancet, ii, 234.

PITT-RIVERS, R., STANBURY, J. B., and RAPP, B. (I955), F. clin. Endocr., r5, 616 .

RAWSON, R. W., RALL, J. E., PEARSON, O. H., ROBBINS, J POPPELL, H. J., and WEST, C. D. (1935), Amer. F. med. Sci.,

ROCHE, J., LISSITZKY, S., and MICHEL, R. (1952a), C.F.

Acad. Sci. (Paris), 234, 997. $234,1228$.

ROCHE, J., and MICHEL, R. (1954), Acta endocr., 17, 385.

ROCHE, J., MICHEL, R., JOUAN, P., and WOLF, W. (1955), C.R. Acad. Sci. (Paris), 24I 880 .

ROCHE, J., MICHEL, R., NUNEZ, J., and WOLF, W. (1955),

Ibid., I49, 884 .
ROCHE, J., MICHEL, R., and TATA, J. (1954), Biochim. biophys. Acta, 15, 500. TAUROG, A., WHEAT, J. D., and CHAIKOFF, I. L. (1956),

THIBAULT, O., and PITT-RIVERS, R. (I955), Lancet, 1, 285. TROTTER, W. R. (I955), Ibid., ii, 374

TROTTER, W. R. (1956a), Ibid., i, 88. .

TROTTER, W. R. (1956b), 'Ciba Found. Colloq. Endocrinol.' In the press.

VANNOTTI, A. (1956), Ibid. In the press.

WILKINSON, J. H., and FEETHAM, A. J. (1955), Biochem. $\mathcal{F}$. 59, 21.

MACLA, J. H., SPROTT, W. E., BOWDEN, C. H., and MACLAGAN, N. F. (I954), Ibid., 56, 215.

\section{NOTICE OF SPECIAL INTEREST TO SUBSCRIBERS:}

\author{
'WHY NOT HAVE YOUR COPIES OF THIS \\ JOURNAL BOUND INTO YEARLY VOLUMES?'
}

\begin{abstract}
You can have your twelve monthly issues fully bound in dark green pin head cloth. lettered in gilt on spine with name of Journal, Volume Number and year, complete with index at front, for 21 s. Od. post free. A limited number of out of print journals are available to bind into volumes and inake your library complete. Price on application giving details of issues required to complete back volumes

THE FELLOWSHIP OF POSTGRADUATE MEDICINE 60 PORTLAND PLACE, LONDON, W.I
\end{abstract}

WHY NOT HAVE YOUR JOURNALS BOUND? - 